\title{
El sepulcro de Jean Bonaventure Thiéry du Mont, conde de Gages, obra del escultor académico Roberto Michel, a través de la mirada de eruditos y viajeros
}

\author{
The sepulchre of Jean Bonaventure Thiéry du Mont, \\ Count of Gages, work of the academic sculptor Roberto Michel, \\ through the eyes of scholars and travelers
}

María Josefa TARIFA CASTILLA

Universidad de Zaragoza

Recibido: 24-II-2017

Aceptado: 25-V-2017

RESUMEN: El presente artículo estudia el sepulcro de Jean Bonaventure Thiéry du Mont (1682-1753), conde de Gages, destacado militar belga y político al servicio del monarca español Felipe V, labrado por el escultor académico Roberto Michel (1767). La consulta de fuentes literarias y archivos locales y nacionales desvela la génesis del proyecto funerario con propuestas de distintos diseños, y la visión que tuvieron del mausoleo los eruditos y viajeros que lo contemplaron en los diferentes emplazamientos en los que estuvo, el originario en la iglesia de capuchinos de Pamplona y su posterior traslado a la catedral y claustro de dicha seo.

Palabras clave: Escultura funeraria, Roberto Michel, Conde de Gages, Siglo XVIII, Pamplona.

ABSTRACT: This article studies the sepulchre of Jean Bonaventure Thiéry du Mont (1682-1753), Count of Gages, a prominent Belgian military and politician to the service of the Spanish monarch Philip V. Tomb carved by the academic sculptor Roberto Michel (1767). The consultation of literary sources and archives reveals the different designs proposed in the genesis of the funerary project, and the vision that the scholars and travelers had of the mausoleum when it was in the Capuchins' church of Pamplona and his later movement to the cathedral first and later to its cloister.

Keywords: Funerary sculptor, Robert Michel, Count of Gages, XVIII century, Pamplona.

\section{EL MAUSOlEO DEL CONDE DE GAGES, PROPAGADOR DE SU FAMA PÓSTUMA}

Jean Bonaventure Thiéry du Mont (1682, Mons, Bélgica-†1753, Pamplona), fue uno de los militares belgas y políticos más notables del reinado de Felipe $V^{1}$. Sirvió en

${ }^{1}$ T. DÍAZ CACHERO, “Thierry Dumont, Juan
Buenaventura", en Gran Enciclopedia de Navarra, vol. X, Pamplona, 1990, p. 472. J. DEL BURGO, Historia General de Navarra. Desde los orígenes hasta nuestros días, T. III, Madrid, 1992, pp. 161-164. M. M. FELICES DE LA FUENTE, La nueva nobleza titulada de España y América en el siglo XVIII (1701-1746). Entre el mérito y la venalidad, Almería, 2012, pp. 258-259. ÍDEM, Condes, marqueses y duques: biografias de nobles titulados durante el reinado de Felipe V, Madrid, 2013, pp. 116-117. 
el regimiento de la Guardia de Infantería Walona, donde ingresó en 1703 y promocionó hasta el grado de teniente coronel de dicha unidad en 1746. En el escalón regular del ejército obtuvo, entre otros, los grados de mariscal de campo (1732), con el que sirvió en la expedición de Orán, en Flandes y en Italia; de teniente general (1734), que alcanzó tras regresar de Italia; y de capitán general de los ejércitos (1743), nombramientos a los que se sumaron diversos honores, entre los que destacan el ingreso como caballero de la Orden de Santiago en $1727^{2}$, la concesión de un hábito de la orden italiana de San Genaro y la merced de gentilhombre de Cámara del rey Carlos, cuando reinaba en las Dos Sicilias.

En 1742 fue designado comandante en jefe del ejército español en Italia, donde consiguió importantes victorias durante la Guerra de Sucesión de Austria frente al ejército austríaco, como las de Campo-Santo (1743), Velletri (1744) y Bassignano (1745), batalla esta última gracias a la que logró apoderarse de Milán, conquistas que fueron recompensadas por el rey con la distinción del Toisón de Oro $(1745)^{3}$ y el título de conde de Gages $(1745)^{4}$, además de las encomiendas de Villoria y Pozuelo, de las Órdenes de Santiago y Calatrava, respectivamente, en 1746. Con la llegada al trono de Fernando VI, Thiéry se estableció en España, siendo nombrado en 1749 virrey $^{5}$, gobernador y capitán general de Navarra, así como presidente de su consejo, cargos en los que permaneció hasta el momento de su fallecimiento acaecido el 31 de enero de 1753.

Siguiendo el espíritu de reformas de la época propuestas por el marqués de la Ensenada, el conde de Gages dio inicio en tierras navarras a una política de obras públicas y

\footnotetext{
${ }^{2}$ Archivo Histórico Nacional (en adelante AHN), Órdenes Militares, Caballeros, Santiago, Expediente 2525.

${ }^{3}$ AHN, Estado, Legajo 7684, Expediente 59.

${ }^{4}$ AHN, Consejos, Legajo 8978, Expediente 830.

${ }^{5}$ Ibídem, Libro 538, fol. 95r.
}

transformaciones urbanísticas, promoviendo la mejora de las comunicaciones con la construcción del Camino Real de Pamplona a Aragón pasando por la Ribera y el proyecto de un canal en el Ebro 6 . En la capital pamplonesa levantó dos nuevos fuertes en el recinto amurallado, el de Guadalupe y el de Los Reyes en el portal de Francia, y convirtió en paseo arbolado el camino que llevaba hasta el convento de los capuchinos situado extramuros de la ciudad, complejo arquitectónico que había sido edificado en el siglo XVII gracias a la generosidad del noble navarro Gabriel de Amasa ${ }^{7}$, y en cuya iglesia barroca de planta de cruz latina recibió sepultura du Mont tras morir en Pamplona el último día de enero de 1753. Templo en el que el propio Gages había solicitado ser enterrado como un fraile más, con sencillez y austeridad, sin ningún tipo de solemnidad ni ostentación en lo que a la celebración religiosa del funeral y sepultura se refiere. Elección de emplazamiento que vino dada por la estrecha relación que el conde había mantenido a lo largo de su vida con los hermanos de la orden capuchina por toda Europa ${ }^{8}, y$ como deferencia hacia los religiosos del convento pamplonés que le habían asistido durante su enfermedad, deseo que el patronato privativo de la iglesia le concedió, haciendo una excepción singular, dada la calidad del personaje.

${ }^{6}$ A. MENDIOROZ LACAMBRA, "El conde de Gages, virrey de Navarra durante 1749-1753", Cuadernos del Marqués de San Adrián, n o 5, 2007, pp. 119-152.

7 T. DE AZCONA, El convento de Capuchinos Extramuros de Pamplona (1606-2006), Pamplona, 2006. M. C. GARCÍA GAINZA, M. ORBE SIVATTE, A. DOMEÑO MARTÍNEZ DE MORENTIN y J. J. AZANZA LÓPEZ, Catálogo Monumental de Navarra, $V^{* * *}$. Merindad de Pamplona, Pamplona, 1997, pp. 361-364.

${ }^{8}$ Dos días después de la entrada del conde de Gages en Pamplona, el 8 de mayo de 1749, el Padre de los capuchinos lo visitó, recibiéndole el virrey "con las mayores expresiones de cariño, danto a entender que estimaba mucho a los Capuchinos". Archivo Histórico Central Capuchinos de Pamplona (en adelante AHCCP), Libro de Anotaciones del Convento de Capuchinos de Pamplona (1679-1833), p. 104. 
El Padre capuchino fray Tomás de Burgui (1721-1774) ${ }^{9}$, excelente orador sagrado, realizó por encargo del gobernador militar, Jaime Silva, la oración fúnebre por su amigo, Retrato vivo del héroe bélgico-hispano virrey Conde de Gages $(1753)^{10}$, que tuvo lugar en la catedral pamplonesa, una pieza extraordinaria desde el punto de vista literario que contiene muchos datos de la biografía del personaje, ponderando sus sonadas victorias, joya literaria que más tarde y de forma detallada conoció varias ediciones, como la de Pamplona de $1764^{11}$. El destacado orador sagrado quiso también iniciar esta obra como un obsequio de la comunidad capuchina de extramuros de Pamplona al conde de Gages, lugar en el que, como acabamos de referir, fueron depositados sus restos mortales. En la edición madrileña de 1766 se indica que el cuerpo del virrey fue amortajado con el hábito capuchino y sobre él la librea correspondiente a su rango de teniente general del regimiento de la Guardia de Infantería Walona, siendo enterrado en la parte central del suelo de la capilla de San Francisco y santos de la orden ${ }^{12}$. Sin embargo, los testamentarios del militar belga consideraron que su humilde sepultura merecía tener algún tipo

${ }^{9}$ F. J. CABODEVILLA, Escritores de las antiguas Provincias Capuchinas de Aragón y Navarra (1608-1900), Pamplona, 2004, pp. 203-212.

${ }_{10}$ T. DE BURGUI, Retrato vivo del héroe bélgicohispano ya difunto: Epicedio obsequioso, que la Seraphica Comunidad de RR. PP. Capuchinos de Pamplona consagró el día 3 de Febrero en sus primeras exequias a la celebre memoria de su insigne bienhechor, el Excelentissimo Don Juan Buenaventura Dumont, Conde de Gages, Capitan General, y Virrey del Reyno de Navarra, Pamplona, 1753. Biblioteca Central Capuchinos de Pamplona. 456/1/10 (2).

${ }^{11}$ T. DE AZCONA, "El P. Tomás de Burgui y su libro sobre San Miguel de Excelsis", Boletín de la Real Sociedad Vascongada de los Amigos del País, LXIV, 2008, pp. 939 y 942. F. IDOATE, “Virreinato del conde de Gages", Rincones de la historia de Navarra, vol. III, Pamplona, 1979, pp. 104-108.

12 T. DE BURGUI, Honras del excelentísimo conde de Gages, Virrey de Navarra y del catholico rey de España don Fernando VI, predicadas en Pamplona por el Padre Fray Thomas de Burgui, Madrid, 1766, p. 117 y 119. de distinción, como así se hizo a lo largo del año de 1753.

La obra del Padre Burgui refiere en la impresión de 1766 que "en una pared de la misma Capilla, donde el cadaver fue sepultado en tierra, se preparó un hueco proporcionado a la colocación de la caja, trabajando a la parte exterior un decente adorno, sobre materia, y molduras de hiesso pintado, y en partes dorados, en que se lee el Nombre del conde de Gages, se ven sus insignias Militares, sus divisas, y blasones, y se representan al desengaño los tristes tropheos de la muerte"13. Y continúa el relato: “Estando ya asi preparado el sitio, y llegado el dia 28 de Enero del siguiente año de 1754, acudieron a los que tenian las tres llaves de la caja del Difunto, la qual fue abierta en presencia del Superior del Convento, y muchos Religiosos suyos; asistiendo tambien presentes Don Gavino Ester y Monserrat, Comisario de Guerra, y antes Secretario, y Testamentario del mismo Excelentissimo Difunto, don Miguel Geronymo Elizalde, Escribano Real. Vista la identidad del cadaver por todos los presentes, se bolvio a cerrar la caja con las mismas llaves y luego fue elevada, y colocada en la pared, en frente del Altar, y quedó cubierta con una gran Lápida blanca, en que el cincel havia gravado una inscripción de algunas proezas de su vida. De todo esto Dio Testimonio el dicho Escribano, y quedó autenticado en forma de Auto público. Después de este obsequio practicado con el cuerpo del Difunto, se sufragó a su Alma con la celebración de un funeral Oficio. El Epitaphio, gravado en su Lápida Sepulcral, es del siguiente tenor:

\author{
COMITI DE GAGES \\ BELLI, TOGAE, MILITIAE, HEROUM HEROI; \\ SUPREMO REGIS CATHOLICI COPIARUM \\ DUCUM DUCI; \\ QUI, SICUT SEIPSUM, URBES, \\ PROVINCIAS, REGNA, \\ AR CESQUE SUBEGIT, HOSTIUM \\ EXERCITUS INVERTIT;
}

${ }^{13}$ Ibídem, p. 121. 


\author{
ET ITALIA FERE OMNI PERAGRATA, \\ VICTORIIS SE CUMULAVIT. \\ PROREGI NAVARRAE, \\ UBI, QUIS FUERIT, SUAE VIRTUTES \\ CONCINNANT; QUID MI- \\ NISTRAVERIT, SUA JUSTITIA DICAT; \\ QUID DENIQUE FECE- \\ RIT, NAVARRI, HUIC REGIAS VIAS, \\ DUCTUS AQUARUM, \\ FIRMISSIMOS PONTES, ARBORES SATAS, \\ REGNIQUE AUGMEN- \\ TUM, SAEPE DEBERI, MEMINERINT \\ GRATI, IN TANTI \\ BONI PIGNUS. \\ HIC QUIESCIT, QUI MIGRAVIT E VITA \\ DIE 31. JANUARII, ANNI 1753"14.
}

Por tanto, un testimonio sumamente interesante, ya que el Padre Burgui no sólo da noticia de cuál fue el primer enterramiento que recibió el virrey, siendo sepultado inicialmente en la capilla de San Francisco y de los santos Fidel de Sigmaringa y José de Leonisa, canonizados en 1746, adosada a la cabecera recta del templo por el lateral izquierdo, sino que además trascribe la inscripción laudatoria de la tumba y expresa que se grabaron armas y trofeos del difunto "en la pared de dicha capilla, que hacía frente al altar della"15.

La brillante carrera del conde de Gages al servicio de la corona española fue recono-

\footnotetext{
${ }^{14}$ Ibídem, pp. 121-122. Una inscripción laudatoria que en castellano viene a expresar: "Al Conde de Gages al héroe de los héroes de la guerra, de la elocuencia jurídica y de la milicia; al supremo capitán general de los generales de los ejércitos del Rey Católico: quien, como para sí mismo, sometió ciudades, provincias, reinos y fortalezas, y venció al ejército de los enemigos; y recorrida casi toda Italia se engrandeció en las victorias. Al Virrey de Navarra, donde, quién habrá estado presente, predique sus virtudes; (a) quién habrá gobernado, celebre su justicia; qué habrá realizado finalmente, los caminos reales, los acueductos, los puentes solidísimos, las plantaciones de árboles y el progreso del Reino, los navarros de éste siempre serán deudores y lo recordarán agradecidos, como prueba de tanto bien. Aquí descansa, quien emigró de la vida el día 31 de Enero, del año 1753".
} 135.

${ }^{15}$ T. DE AZCONA, El convento de Capuchinos..., p. cida de manera honorable por el monarca Carlos III, quien años después ordenó erigir a costa de la real hacienda un mausoleo en su honor, monumento funerario que además de albergar sus restos mortales debía pregonar la fama de sus hazañas militares, "cuya Arquitectura, adornos significativos y inscripción en lapida correspondan al deseo de S.M. y honor de aquel grande general" ${ }^{\prime 16}$. Un proyecto que se dilató en el tiempo, desde su inicio en 1760 hasta su conclusión definitiva en 1767, y para el que al menos se idearon dos diseños gráficos de sepulcro parietal, que finalmente no se llevaron a la práctica, pero que se conservan en el Archivo General de Simancas. Uno de ellos fue acometido en 1760 por Juan Lorenzo Catalán ${ }^{17}$, maestro de obras reales en Pamplona y uno de los artistas que participó en los proyectos arquitectónicos más relevantes erigidos en la capital navarra a mediados del siglo XVIII, tanto civiles como religiosos. La nueva casa consistorial de Pamplona, construida entre 1753 y 1759, fue dotada de una nueva fachada, cuyo coronamiento responde al diseño clasicista propuesto en abril de 1756 por Catalán ${ }^{18}$. Asimismo participó junto con otros artífices en el diseño de la nueva capilla de la Virgen del Camino en la iglesia parroquial de San Saturnino de Pamplona (1757-1776) ${ }^{19}$,

\footnotetext{
${ }^{16}$ Archivo General de Simancas (en adelante AGS), Secretaría de Guerra, Legajo 3278.

${ }^{17}$ AGS, Mapas Planos y Dibujos, 62,039.

18 J. L. MOLINS MUGUETA, "Trazas y dibujos de la antigua Casa Consistorial de Pamplona", en R. FERNÁNDEZ GRACIA (coord.), Pulchrum. Scripta Varia in honorem $M^{a}$ Concepción García Gainza, Pamplona, 2011, pp. 560 y 563.
}

${ }^{19}$ J. L. MOLINS MUGUETA y R. FERNÁNDEZ GRACIA, "La capilla de Nuestra Señora del Camino", en La Virgen del Camino de Pamplona. IV Centenario de su aparición (1487-1997), Pamplona, 1987, pp. 68 y 78. J. L. MOLINS MUGUETA “Las capillas de San Fermín y de Nuestra Señora del Camino en Pamplona", en M. C. GARCÍA GAINZA (coord.), El arte en Navarra. 2. Renacimiento, Barroco y del Neoclasicismo al arte actual, Pamplona, 1994, p. 426. M. C. GARCÍA GAINZA, M. ORBE SIVATTE, A. DOMEÑO MARTÍNEZ DE MORENTIN y J. J. AZANZA LÓPEZ, Op.cit., p. 123. R. FERNÁNDEZ GRACIA, (coord.), P. ANDUEZA 


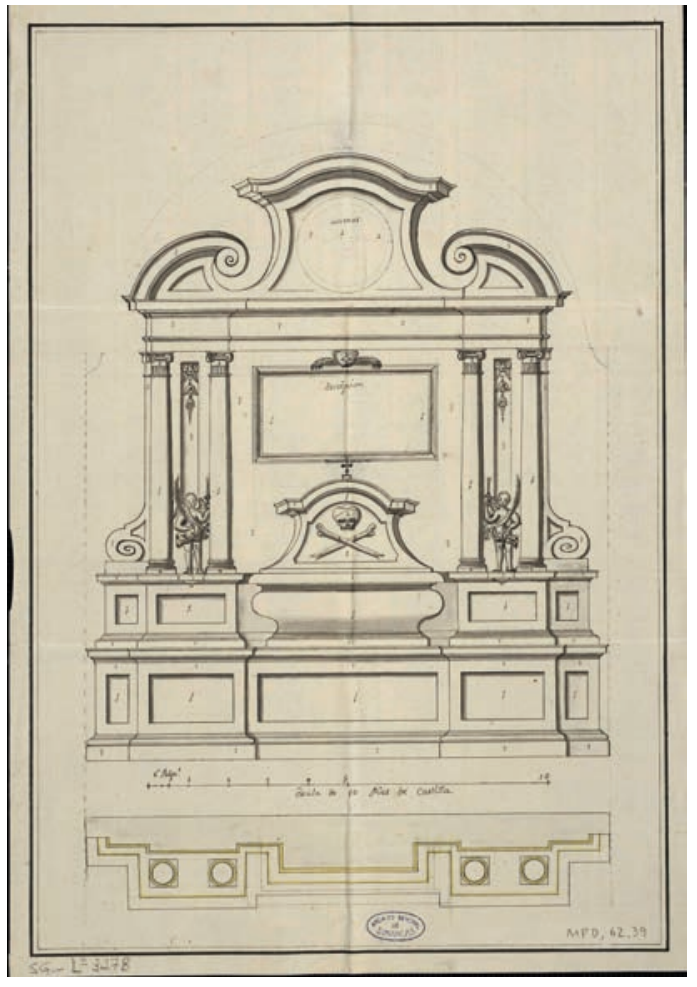

- Fig. 1. Juan Lorenzo Catalán. Planta y alzado del Mausoleo del conde de Gages. 1760. España. Ministerio de Educación, Cultura y Deporte. Archivo General de Simancas, MPD, 62,039.

proporcionando igualmente dibujos en 1759 para la fachada de la capilla de San Fermín en la iglesia de San Lorenzo de la capital navarra $^{20}$, las trazas conforme a las que fue erigida la biblioteca capitular de la catedral de Pamplona a partir de $1760^{21}$ y un dibujo para la nueva fachada de la catedral que el cabildo decidió construir a partir de $1782^{22}$, estos dos últimos proyectos irrealizados.

El diseño ideado por Catalán para el sepulcro del conde de Gages (Fig. 1), en cuya labra se emplearían jaspe negro, alabastro

UNANUA, J. J. AZANZA LÓPEZ y M. C. GARCÍA GAINZA, El arte del Barroco en Navarra, Pamplona, 2014, pp. 25-26 y 145.

${ }^{20}$ J. L. MOLINS MUGUETA, Capilla de San Fermín en la iglesia de San Lorenzo de Pamplona, Pamplona, 1974, p. 58 , fig. 8 .

${ }^{21}$ R. FERNÁNDEZ GRACIA, "Barroco", en La Catedral de Pamplona, vol. II, Pamplona, 1994, p. 38.

${ }^{22}$ M. LARUMBE MARTÍN, "Neoclasicismo", en Ibídem, vol. II..., pp. 76-77. blanco y bronce sobredorado, muestra un mausoleo delimitado por un arcosolio curvo compuesto por un plinto de frentes cajeados al que sucede el basamento de igual factura, a los que se adosan dos cuerpos laterales retranqueados con los frentes igualmente cajeados. El cuerpo se divide en tres calles articuladas por pares de columnas clásicas, en cuyos intercolumnios se disponen ángeles que sustentan velas y antorchas en sus manos. La parte central de la hornacina acoge la urna sepulcral, de diseño curvo, en cuya parte superior se ha dibujado una calavera con dos tibias cruzadas, quedando ocupada la pared frontal por un marco rectangular rematado por una cabeza de tigre con garras, en el que se labraría el epitafio. Remata el conjunto un ático de frontón ondulado y volutas curvas en los extremos.

El otro proyecto de monumento funerario fue ejecutado en noviembre de 1764 por Francisco Llobet (1705-1785) (Fig. 2) ${ }^{23}$,

${ }^{23}$ AGS, Mapas, Planos y Dibujos, 60,030.

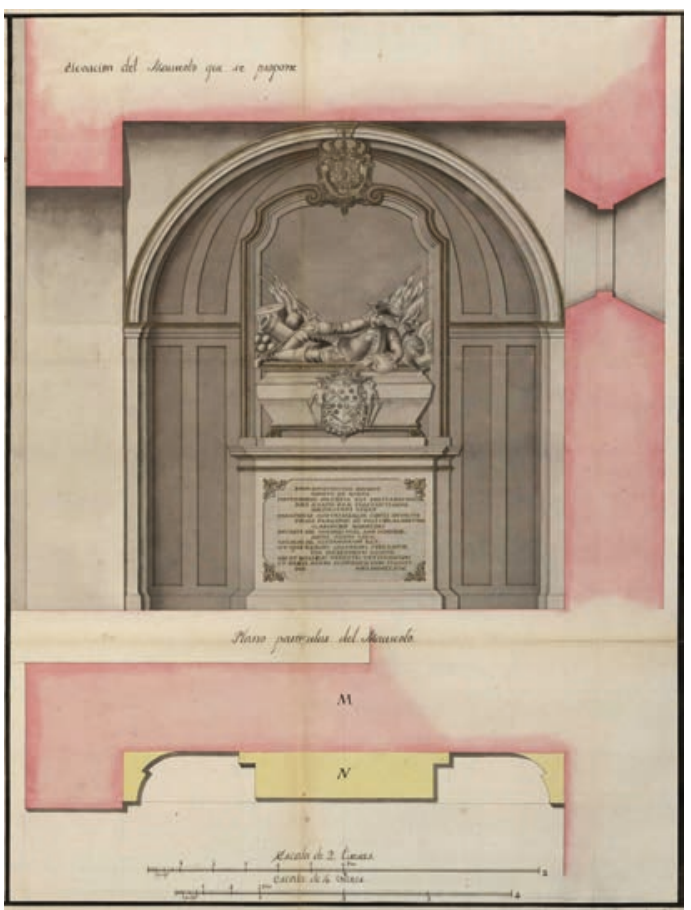

- Fig. 2. Francisco Llobet. Proyecto del mausoleo del conde de Gages. 1764. España. Ministerio de Educación, Cultura y Deporte. Archivo General de Simancas, MPD, 60,030.. 
ingeniero militar, urbanista y arquitecto español $^{24}$, que se encontraba trabajando por estas fechas en Pamplona ${ }^{25}$, acompañado del plano de la iglesia de los padres capuchinos donde debía disponerse el mausoleo ${ }^{26}$ (Fig. 3), no en el lateral derecho de la única nave de la iglesia, sino en la misma capilla donde reposaban los restos del conde de Gages, adosada a la cabecera por el lateral del evangelio. Un sepulcro ubicado en el interior de una hornacina poco profunda, delimitado por pilastras de orden toscano y un arco de medio punto, decorado en su interior con recuadramientos geométricos. Sobre un alto basamento rectangular, en cuyo frente se ha copiado un largo epitafio en latín con letras capitales, apoya la urna sepulcral lisa, de diseño trapezoidal, con el escudo del conde labrado en su frente. Sobre la tapa se recuesta la figura del difunto de cuerpo entero, no tumbado totalmente, sino apoyado en el codo izquierdo y con la mano derecha sobre la rodilla doblada, vestido a la usanza de la época, rodeado de banderas, cañones y otros trofeos de guerra, coronando el marco rectangular de remate curvo en la parte superior que encuadra el conjunto funerario el escudo real. Una sepultura que el artista pro-

${ }^{24}$ Uno de sus planos más conocidos es el dibujo del mapa territorial del reino de Sevilla de 1748. A. LÓPEZ GÓMEZ y C. MANSO PORTO, Cartografía del siglo XVIII: Tomás López en la Real Academia de la Historia, Madrid, 2006, p. 67. Entre sus numerosos destinos, en la década de 1750 trabajó en la fortificación de la frontera portuguesa de Galicia. A. CÁMARA MUÑOZ, Los ingenieros militares de la monarquía hispánica en los siglos XVII y XVIII, Madrid, 2005, pp. 255-256.

${ }^{25}$ Este mismo año de 1764 dibujó un plano de los caminos construidos en la vega del río Ebro en el término de Pozalobos, con el trazado del camino nuevo de Tudela hasta Aragón, en el que había puesto especial empeño el conde de Gages, conservado en el Archivo General de Navarra. M. LARUMBE MARTÍN, El academicismo y la arquitectura del siglo XIX en Navarra, Pamplona, 1990, pp. 40-41.

${ }^{26}$ AGS, Mapas, Planos y Dibujos, 60,030. El plano presenta la siguiente leyenda: "Plano de la Yglesia de Padres Capuchinos extramuros de la Plaza de Pamplona, donde yaze el difunto conde de Gages y Proyecto de un Mausoleo que la Real Piedad desea se erija para perpetuar su Memoria".

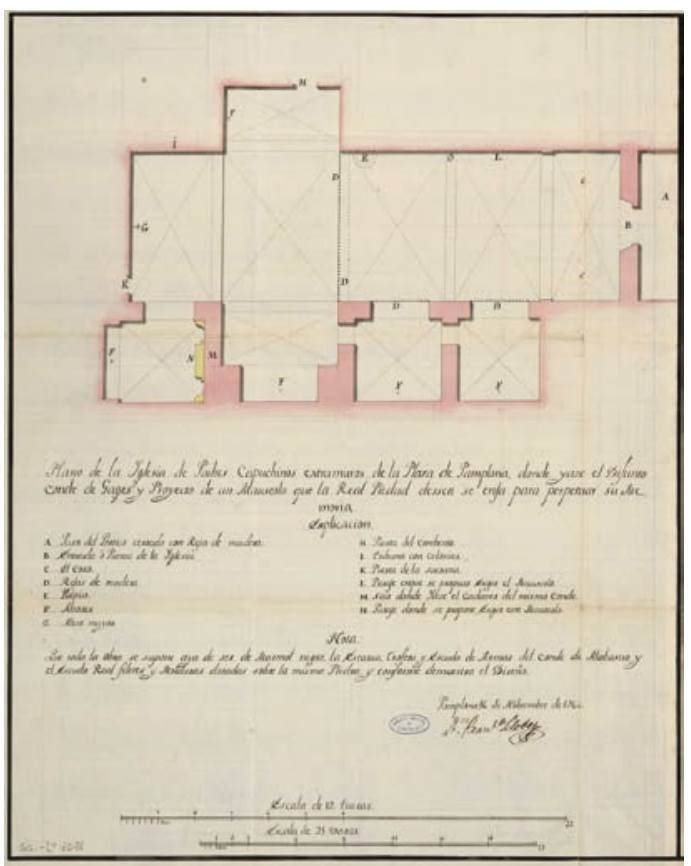

- Fig. 3. Francisco Llobet. Planta de la iglesia de los padres capuchinos de Pamplona. 1764. España. Ministerio de Educación, Cultura y Deporte. Archivo General de Simancas, MPD, 60,030 .

ponía ejecutar con mármol negro, alabastro y bronce dorado.

El sepulcro de mármol que finalmente fue tallado sin seguir los diseños anteriormente descritos, fue colocado en 1767 en la iglesia del referido convento pamplonés, "en la pared de entre las dos capillas por el lado del evangelio y así se ha executado adonde han trasladado los huesos y cadáver de dicho excmo señor Gages con las armas reales encima y también las del dicho excmo Señor Conde de Gajes y puesto su escultura de medio cuerpo con las armas reales encima y tambien las de dicho excmo señor Conde de Gajes" ${ }^{\prime 27}$. Sin embargo, el 6 de octubre de 1767 los patronos del convento acordaron "que se quiten las armas y trofeos que estan en dicha capilla en la referida iglesia con objeto de que en ningun modo perjudiquen al

27 T. DE AZCONA, El convento de Capuchinos Extramuros..., p. 135. AHCCP. Fundación Amasa, Legajo 5 , fol. $90 \mathrm{v}$ 
patronato privativo de dicho señor Gabriel de Amasa" ${ }^{28}$.

Un mausoleo excepcional, tanto por el promotor que lo hizo posible, el propio monarca Carlos III, como por el artista que finalmente lo llevó a cabo, el escultor académico Roberto Michel (1720-1786), uno de los principales escultores cortesanos del periodo borbónico, que llegó a ser teniente director de escultura de la recién creada Real Academia de Bellas Artes de San Fernando (24 de abril de 1752), escultor de Cámara (6 de marzo de 1757) con un sueldo de 9.000 reales anuales, director de esa especialidad en la referida Real Academia (4 de diciembre de 1763), primer escultor de Cámara (29 de septiembre de 1775) con un sueldo de 15.000 reales de vellón anuales, y director general de la institución (1785-1786). De origen francés, originario de Puy de Velay (Languedoc), en cuyo país se formó bajo el magisterio del flamenco Luquet en Toulouse, entre otros, Michel llegó a España en 1740 para participar en la labor escultórica del Palacio Real Nuevo, quedando incluido en el grupo del escultor neoclásico Felipe de Castro. Desarrolló una importante actividad como estucador, ornamentando, entre otros edificios, los Palacios de Madrid, San Ildefonso, Aranjuez y El Pardo. Entre las obras salidas de sus manos destacan algunas estatuas de reyes para el Palacio Real Nuevo, como la de Teudis, Alfonso IV, Bermudo III, Sancho I el Craso y Fernando II; los dos leones que arrastran el carro de la fuente de la Cibeles, diseñada por Ventura Rodríguez (1776), o la decoración con trofeos militares, cabezas de leones, cornucopias y ángeles en mármol de la Puerta de Alcalá, construida por Sabati$\mathrm{ni}^{29}$.

${ }^{28}$ AHCCP, Fundación Amasa, Legajo 5, fol. 90v.

29 Algunos de los estudios que en las últimas décadas se han publicado sobre este artista francés, son los de J. J. MARTÍN GONZÁLEZ, Escultura barroca en España, 1600-1770, Madrid, 1983, pp. 405-407. J. L. MELENDRERAS GIMENO, "La obra de Roberto Michel escultor de Cámara del Rey Carlos III", Reales sitios, nº 90, 1986, pp. 37-44. M. L. TÁRRAGA BALDÓ, "Los estucos de Roberto Michel para el palacio de El
A Michel, artista versátil con habilidad para trabajar en distintos materiales con gran destreza y rapidez, desde mármol, piedra, bronce, hasta yeso o madera, se le documentan en Navarra las cinco esculturas de los retablos de la basílica de San Gregorio Ostiense (Sorlada), la del titular, Santo Domingo de la Calzada y San Juan de Ortega en el retablo mayor, y las de San Joaquín y San Isidro labrador en los colaterales ${ }^{30}$, que llegaron en 1768 tras uno de los viajes de la Santa Cabeza por gran parte de España con el beneplácito del mismo rey Fernando VI. Posiblemente también sean de su mano las tallas del Niño Jesús y San Juanito de la sacristía de la catedral de Pamplona ${ }^{31}$, estando su labor en ambos conjuntos religiosos referidos asociada a la del destacado escultor Silvestre de Soria ${ }^{32}$, también formado en la corte.

En este emplazamiento de la capilla de San Francisco de la iglesia del convento pamplonés de los capuchinos vio el sepulcro del conde de Gages el valenciano Antonio Ponz cuando visitó la ciudad, tal y como dejó es-

Pardo", Archivo Español de Arte, LXII, no 247, 1989, pp. 315-329. ÍDEM, "Carlos III y la escultura cortesana", Reales Sitios, no 99, 1989, pp. 35-44. L. AZCUE BREA, La escultura en la Real Academia de Bellas Artes de San Fernando. Catálogo y estudio, Madrid, 1994, pp. 5-6 y 171-173. C. LORENTE ARÉVALO y C. TASCÓN GÁRATE, "Nuevas aportaciones a la biografía del escultor Roberto Michel", Anales de Historia del Arte, $\mathrm{n}^{\mathrm{o}}$ 5, 1995, pp. 225-236. M. DEL R. GUTIÉRREZ MARCOS, "Roberto Michel: introductor del clasicismo francés en la imaginería de la iglesia de San José de Madrid", Ars et sapientia, nº23, 2007, pp. 45-62. J. A. SÁNCHEZ RIVERA, "Robert Michel en la iglesia de las Comendadoras de Santiago", Anales del Instituto de Estudios Madrileños, L, 2010, pp. 353-373.

${ }^{30}$ M. C. GARCÍA GAINZA, M. C. HEREDIA MORENO, J. RIVAS CARMONA, y M. ORBE SIVATTE, Catálogo Monumental de Navarra, II**. Merindad de Estella, Pamplona, 1983, pp. 509-511. M. C. GARCÍA GAINZA, Escultura cortesana del siglo XVIII, Madrid, "Historia 16", no 92, 1993, pp. 28-30.

31 R. FERNÁNDEZ GRACIA, “Los géneros escultóricos", en R. FERNÁNDEZ GRACIA, (coord.), P. ANDUEZA UNANUA, J.J. AZANZA LÓPEZ y M.C. GARCÍA GAINZA, Op.cit., p. 244.

${ }^{32}$ Sobre este artista navarro, natural de la localidad de Sesma, véase Ibídem, pp. 217-219. 
crito en el segundo tomo de su Viaje fuera de España (1785), en la carta XII: “En el convento de Capuchinos, que dista como un cuarto de legua de la Ciudad por su lado Norte, está el Sepulcro de mármoles del General Gages, que le hizo erigir S.M. y consiste en una urna sobre basamento, en el cual hay dos niños, y en medio el escudo de armas Reales en bronce. Hizo dicha obra D. Roberto Michel, Director de la Real Academia de S. Fernando, y Escultor de S.M." ${ }^{33}$.

Ponz es el primer escritor que ofrece la noticia de la autoría del sepulcro del conde de Gages en la persona de Roberto Michel, de quien fue compañero en el seno de la Real Academia de Bellas Artes de San Fernando, al desempeñar el puesto de secretario de la misma desde 1776. No obstante, la consulta del expediente personal de Michel conservado en el Archivo General de Palacio (Madrid), ha permitido comprobar que el propio artista, cuando solicitó el 26 de agosto de 1775 como director de escultura de la Real Academia de San Fernando, el puesto de primer escultor de Cámara, tras el fallecimiento el día anterior de Felipe de Castro, mencionó las obras acometidas hasta el momento para el monarca en mármol, madera, estuco y bronces, entre las que se refería el mausoleo del conde de Gages, siendo por tanto ésta la primera referencia documental localizada hasta el momento alusiva a la ejecución del sepulcro por parte de $\mathrm{Michel}^{34}$. Asimismo,

33 A. PONZ, Viage fuera de España, (ed. Mónica Bolufer Peruga), Alicante, 2007, p. 825.

${ }^{34}$ Archivo General de Palacio (en adelante AGP), Personal, Caja 679, Expediente 9. Las obras acometidas por Michel hasta el momento, referenciadas en el expediente son "la Real Capilla, y en ella mayor parte de figuras de estuco; el Salon de los Reynos, que todas son de mano del suplicante, la mayor parte de la escalera principal del Real Palacio, y la de Leon de Marmol, de los dos que estan a la subida de ella, el Mayor toda la obra de escultura; y adornos de bronces del Oratorio de V.M. privado todas las figuras, y escudo de Armas Reales de Marmol de la Real Casa de Aduana, el Mausoleo del Exmo. Señor Conde de Gages, que colocó en Pamplona de orden de V.M., y todas las figuras de estuco de la Real Colegiata de San Yldefonso, que concluió hallándose V.M. en aquel Real Sitio, y últimamente toda la obra de cuando unos años más tarde, en febrero de 1786, la viuda del artista, Rosa Ballerna, dirigió una instancia a su majestad solicitando una pensión o consignación diaria ante la situación de pobreza en la que había quedado, volvió a referir todas las obras acometidas por su difunto esposo, entre las que evidentemente se vuelve a citar "el Mausoleo de Marmoles y bronces del Excmo Conde de Gages que coloco en Pamplona de orden de S.M. el año de $1767^{\prime \prime 35}$.

El mausoleo permaneció en este templo franciscano hasta comienzos de la década de 1810, cuando fue llevado al trascoro de la catedral pamplonesa ante el temor de que fuese profanado por las tropas napoleónicas en la Guerra de la Independencia ${ }^{36}$. La consulta de los fondos documentales del Archivo de la Catedral de Pamplona permite fijar la fecha exacta del traslado y conocer el modo en el que fue efectuado. Concretamente, el 26 de noviembre de 1813, el Comandante Militar de Pamplona, Carlos España, solicitó al cabildo catedralicio permiso para depositar el sepulcro del Conde de Gages en dicho templo "a fin de que fuese respetado un monumento tan precioso", ya que "la dicha yglesia de Capuchinos se halla profanada, y que la libertad en que se halla ya la Plaza del Yugo enemigo permite la traslacion de dicho monumento, y cenizas de aquel digno General" $^{\prime 37}$. Los canónigos aceptaron recibir los restos del conde de Gages y su mausoleo a perpetuidad, disponiéndolos en principio "en el trascoro de esta Santa Iglesia baxo la reserva de trasladarlos a otro sitio de la misma Yglesia siempre que el Cabildo lo tubiese por conveniente" y bajo la condición

estuco de la del Real Palacio del Pardo".

${ }^{35}$ Ibídem.

${ }^{36}$ De hecho, el convento sufrió serios daños durante este conflicto bélico, por encontrarse extramuros de la ciudad, teniendo que ser reconstruido a partir de 1815 . T. DE AZCONA, El convento de Capuchinos Extramuros..., pp. 223-226.

${ }^{37}$ Archivo de la Catedral de Pamplona (en adelante ACP), Acuerdos Capitulares, 1808-1815, Libro 24, fol. $109 \mathrm{r}$. 
de que "el desmonte del dicho monumento y su traslacion con las cenizas del difunto sea de cuenta del dicho señor Comandante Militar"38. La llegada de los mismos a la catedral se fijó el el 31 de noviembre de dicho mes a las once de la mañana, con todos los honores militares, debiendo salir el cabildo procesionalmente "a la puerta principal con Cruz y revestido el Señor semanero, y que recibidos se acompañen cantando el Miserere hasta la valla de la Yglesia, y que colocados en esta se diga un responso solemne con música, con lo que se concluirá esta funcion. Despues dichos restos mortales se retiraran privadamente a un parage decente, de lo que cuidara el señor sacristan mayor, y estarán hasta que se coloque el mausoleo con las cenizas del difunto en el trascoro de la Santa Yglesia baxo la reserva" ${ }^{39}$.

En este emplazamiento del trascoro de la seo metropolitana pamplonesa lo admiró el poeta Víctor Hugo, (Besançon, 1802- París, 1885), destacada figura del romanticismo francés, cuando visitó la ciudad en 1843, impresiones que recoge la escritora francesa Gilberte Guillaume-Reicher en el libro Le voyage de Víctor Hugo en 1843. France- EspagnePays Basque, publicado en París en 1936: "Al lado del gran pórtico, el coro está respaldado por un grueso muro al que está adosada una tumba de mármol blanco. El epitafio, en letras de oro casi borradas, indica que allí están los restos de aquel valiente Buenaventura Dumont, conde de Gages, que derrotó en muchas ocasiones a los imperiales y a $\mathrm{M}$. de Savoya en persona. Una de estas refriegas constituye una batalla muy bella que vemos esculpida en bajo relieve encima del epitafio. Hay ahí cañones apuntados, caballos que se encabritan, oficiales que mandan, nutridos batallones que cruzan sus picas y se asemejan a malezas que un viento furioso mezclaría. Nada más extraño que esta refriega petrificada y muda, inmóvil para siempre en esta oscura iglesia en la que de vez en cuando se oye la voz chillona, débil e intermitente

\footnotetext{
${ }^{38}$ Ibídem.

${ }^{39}$ Ibídem, fol. 109v.
}

del niño de coro. Ese gran tumulto que hace la batalla y ese gran silencio que da la tumba dejan en el corazón una grave enseñanza. ¡He aquí pues lo que es la gloria de los hombres de guerra en la muerte!. Se calla. La gloria de los poetas y los pensadores canta y habla eternamente" ${ }^{\prime 4}$.

El Diccionario geográfico-estadístico-histórico de España de Pascual Madoz dedica asimismo un amplio párrafo al mausoleo del virrey cuando aborda la catedral de Pamplona (1849): “...en el trascoro campea el suntuoso mausoleo del conde de Gages: consiste en un zócalo de mármol negro sobre el que asienta el primer cuerpo, que en su delantera muestra una lápida con esta inscripción en letras doradas: Joani Bonaventurae Dumont comiti de Gages Sabaudicis Austriacisque ad velitras et tanarum copiis fugatis, regni neapolitani clarissimo assertori Reique militaris peritia, duci supra famam praeclarissimo tandem, tandem regni Nabarrae prorregi solertissimo. Et in publicis viis strandis inventori mirifico. Decedenti Prid. Kal. Feb. Anno MDCCLIII. Aetatis LXXIII. Carolus III. Hisp. Rex Monumentum hoc benemerenti dicat. A ambos lados se ven los dos hermosos genios de mármol blanco, que con triste ademan apagan en el suelo sus antorchas: dos modillos que hay sobre este cuerpo, sostienen la urna, en cuya parte anterior está representada en relieve la retirada de Campo Santo. Sobre la urna se levanta el busto del anciano virey, coronando el todo las armas reales de España. Este magnífico mausoleo se hizo de orden de Carlos III, y el autor fue el conocido escultor D. Roberto Michel. Hasta la Guerra de la Independencia estuvo en el convento de Capuchinos extramuros de Pamplona, para librarle de los estragos de la guerra, se le trasladó al sitio que ahora ocupa, y al cual no son análogas sus proporciones. Sobre la pared del coro corre un antepecho sencillo de hierro, y en su mitad sobre el sepulcro de Gages se le-

${ }^{40}$ V. HUGO, Los Pirineos (trad. Victoria Argimón), Palma de Mallorca, 2000, pp. 133-134. 
vanta un gran crucifijo, mirando a la puerta principal" $^{\prime 1}$.

En este espacio central del trascoro catedralicio permaneció el mausoleo del conde de Gages hasta comienzos de la década de 1850, cuando aquel se enriqueció con un templete neoclásico de acuerdo al proyecto encargado años atrás en 1830 por el cabildo a Pedro Manuel de Ugartemendía ${ }^{42}$, y que prosiguió a partir de 1854 el arquitecto académico Anselmo Vicuña, inaugurándose el altar del trascoro en $1857^{43}$. Con motivo de dicha reforma, el sepulcro fue trasladado al claustro gótico de la misma catedral, en una fecha hasta el momento sin precisar, apuntando algunos autores el año de $1851^{44}$. La consulta de los fondos documentales de acuerdos capitulares custodiados en el Archivo de la Catedral de Pamplona permite precisar que el 14 de septiembre de 1854 los canónigos reunidos en cabildo extraordinario acordaron "colocar el referido Panteon de Gages en uno de los dos nichos del Claustro

${ }_{41}$ P. MADOZ, Diccionario geográfico-estadísticohistórico de Navarra, Valladolid, 1986, p. 289.

${ }^{42}$ J. GOÑI GAZTAMBIDE, “La capilla del trascoro de la catedral de Pamplona", en Hispania christiana: estudios en honor del prof. Dr. José Orlandis Rovira en su septuagésimo aniversario, Pamplona, 1988, pp. 685-718.

43 M. LARUMBE MARTÍN, "Neoclasicismo", en La Catedral de Pamplona, vol. II..., p. 89. J. RIVAS CARMONA, "El trascoro de Pamplona: el valor de la tradición catedralicia", en M. C. GARCÍA GAINZA y R. FERNÁNDEZ GRACIA, (coords.), Cuadernos de la Cátedra de Patrimonio y Arte Navarro, $n^{0}$ 1. Estudios sobre la catedral de Pamplona in memoriam Jesús María Omeñaca, Pamplona, 2006, pp. 259-272.

${ }^{44}$ J. M. IRIBARREN, Pamplona y los viajeros de otros siglos, Pamplona, 1986, pp. 145-146. F. DE ALVARADO, Guía del viajero en Pamplona, Madrid, 1904, p. 42, quien en realidad se llamaba Mariano Arigita y Lasa, afirma que el traslado de la sepultura tuvo lugar en 1831, lo cual debe interpretarse como una errata tipográfica, dado que Víctor Hugo vio el mausoleo en 1843 en el trascoro. Probablemente Arigita quiso decir 1851. De hecho, al hablar este mismo autor del altar del trascoro, que fue colocado en el lugar que ocupaba hasta entonces el sepulcro del conde de Gages, afirma que las obras fueron interrumpidas a la muerte del arquitecto donostiarra Ugartemendía, siendo reanudadas en 1854 y concluidas en 1857. bajo cercanos al Calvario del Via Crucis"45, siendo dispuesto finalmente en una de las hornacinas existentes en la crujía sur, donde ha permanecido hasta la actualidad (Fig. 4$)^{46}$.

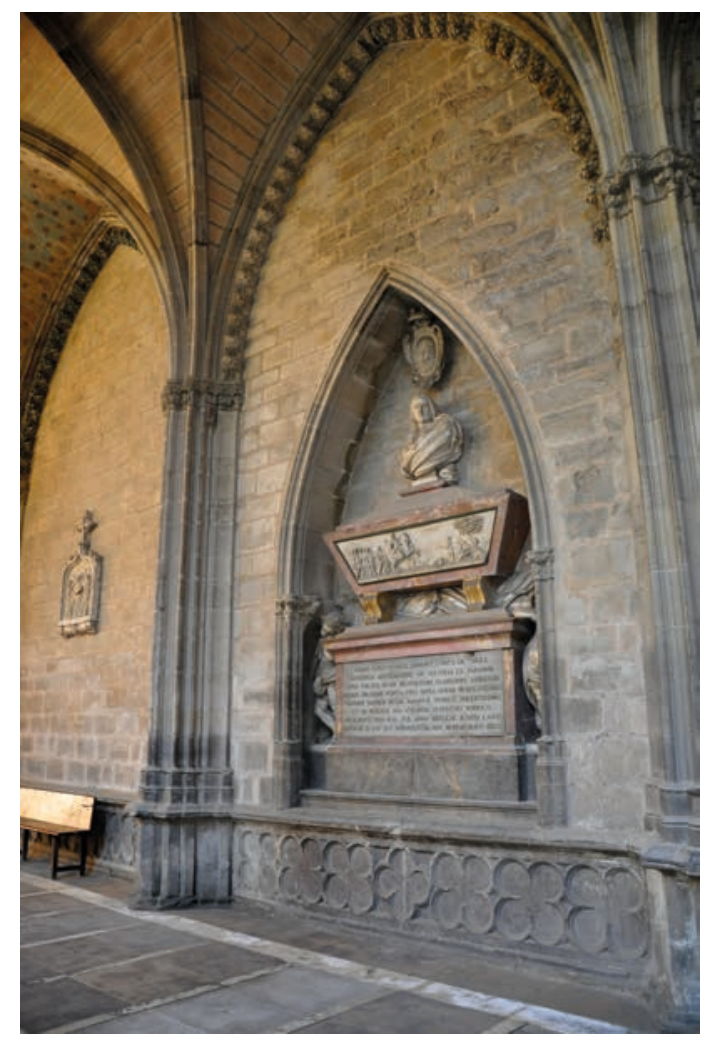

- Fig. 4. Roberto Michel. Sepulcro del conde de Gages. 1767. Claustro de la Catedral de Pamplona. Foto de la autora.

Un monumento funerario que en los años venideros siguió llamando la atención de cuantos viajeros cultos pasaron por la capital navarra, y al que inevitablemente aludieron en sus diarios al describir la catedral pamplonesa. En 1889 el italiano Benedetto Croce (1866-1952), filósofo, crítico e historiador de arte napolitano, efectuó un viaje por España y Portugal que reflejó en su obra $\mathrm{Ne}$ -

${ }^{45}$ ACP, Acuerdos Capitulares, 1847-1863, Libro 29, fol. 202r.

${ }^{46}$ M. C. GARCÍA GAINZA, M. ORBE SIVATTE, A. DOMEÑO MARTÍNEZ DE MORENTIN y J. J. AZANZA LÓPEZ, Catálogo Monumental de Navarra, $V^{* * *}$. Merindad de Pamplona..., pp. 49-50. 
lla Penisola Iberica. Taccuino di viaggio ${ }^{47}$. En su visita a la ciudad de Pamplona en el mes de junio, refirió en sus notas la localización en el claustro catedralicio de la tumba moderna del general Mina y la del conde de Gages, de la que además de describirla, copió la inscripción latina grabada en memoria del difunto.

Una obra escultórica que en las publicaciones científicas que verán la luz a partir del siglo XX seguirá siendo reseñada por la autoría de su ejecutor y el promotor real que la hizo posible ${ }^{48}$.

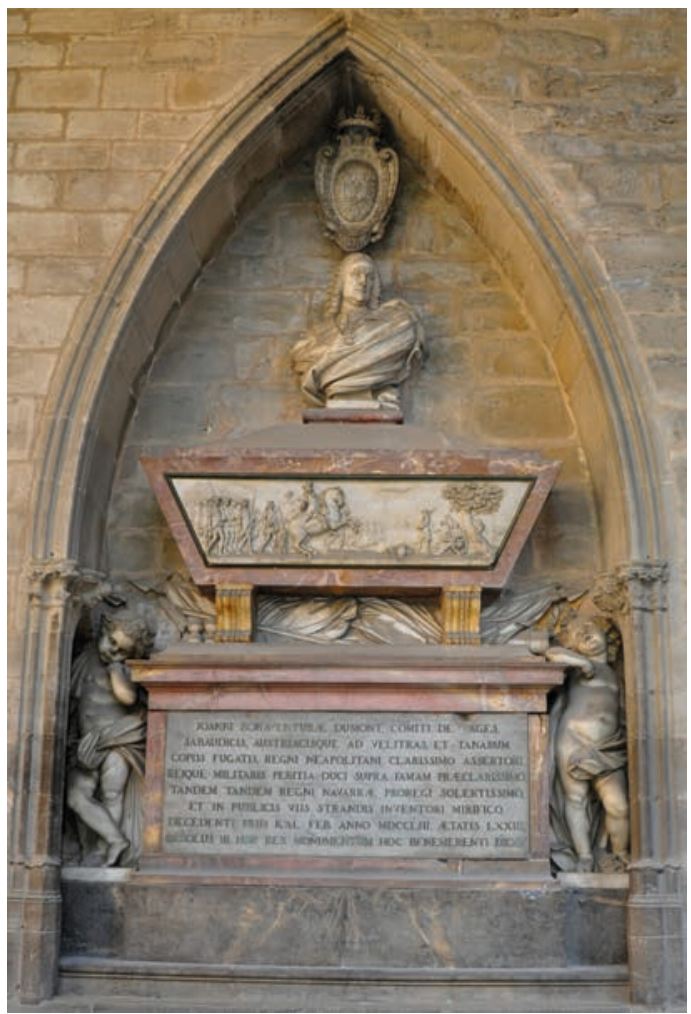

- Fig. 5. Roberto Michel. Sepulcro del conde de Gages. 1767. Claustro de la Catedral de Pamplona. Foto de la autora.

47 J. M. ROMERA, Pamplona-Iruña. Imágenes y palabras, Pamplona, 1997, pp. 160 y 259. El autor recurre a la versión española En la Península Ibérica. Cuaderno de Viaje (1889), (trad. y notas de Félix Fernández Murga), Sevilla, 1993, pp. 102-103.

${ }^{48}$ F. J. SÁNCHEZ CANTÓN, "Roberto Michel, escultor del siglo XVIII", Boletín de la Sociedad Española de Excursiones, XXV, 1917, p. 5.

\section{ANÁLISIS ARTÍSTICO DEL SEPUL- CRO DEL CONDE DE GAGES}

El monumento funerario de Jean Bonaventure Thiéry du Mont se encuentra emplazado desde 1854 en el interior de un arcosolio gótico de la crujía occidental del claustro de Pamplona (Fig. 5). Un espacio angosto dadas las dimensiones de la sepultura, en el que incluso fue necesario rebajar los laterales del mismo con objeto de poder encajar el mausoleo en su interior, lo que dificulta la contemplación de los elementos escultóricos del sepulcro dispuestos en los extremos al quedar embutidos en el interior de la hornacina.

El mausoleo parietal (Fig. 6) se alza sobre un zócalo de mármol negro que sirve de base a un alto cuerpo rectangular realizado en jaspe, enmarcado por las bellas figuras de bulto redondo de dos niños, en cuyo frente de mármol blanco se ha inscrito un largo epitafio en capitales romanas:

JOANNI BONAVENTURAE

DUMONT, COMITI DE GAGES,

SABAUDICIS, AUSTRIACISQUE AD

VELITRAS, ET TANARUM

COPIJS FUGATIS, REGNI

NEAPOLITANI CLARISSIMO

ASSERTORI,

REIQUE MILITARIS PERITIA DUCI

SUPRA FAMAM PRAECLARISSIMO,

TANDEM TANDEM REGNI

NAVARRAE PROREGI

SOLERTISSIMO,

ET IN PUBLICIS VIJS STRANDIS

INVENTORI MIRIFICO,

DECEDENTI PRID. KAL. FEB. ANNO

MDCCLIII, AETATIS LXXIII,

CAROLUS III. HISP. REX

MONUMENTUM HOC

BENEMERENTI DICAT ${ }^{49}$.

49 La inscripción latina refiere: "A Juan Buenaventura Dumont, conde de Gages, que puso en fuga las tropas saboyanas y austriacas en Velletri y el Tanaro, al consejero ilustrísimo del reino napolitano y del Rey con su pericia militar, al general de la fama más extraordinaria, finalmente al ingeniosísimo virrey de Navarra, y diseñador prodigioso de los caminos 


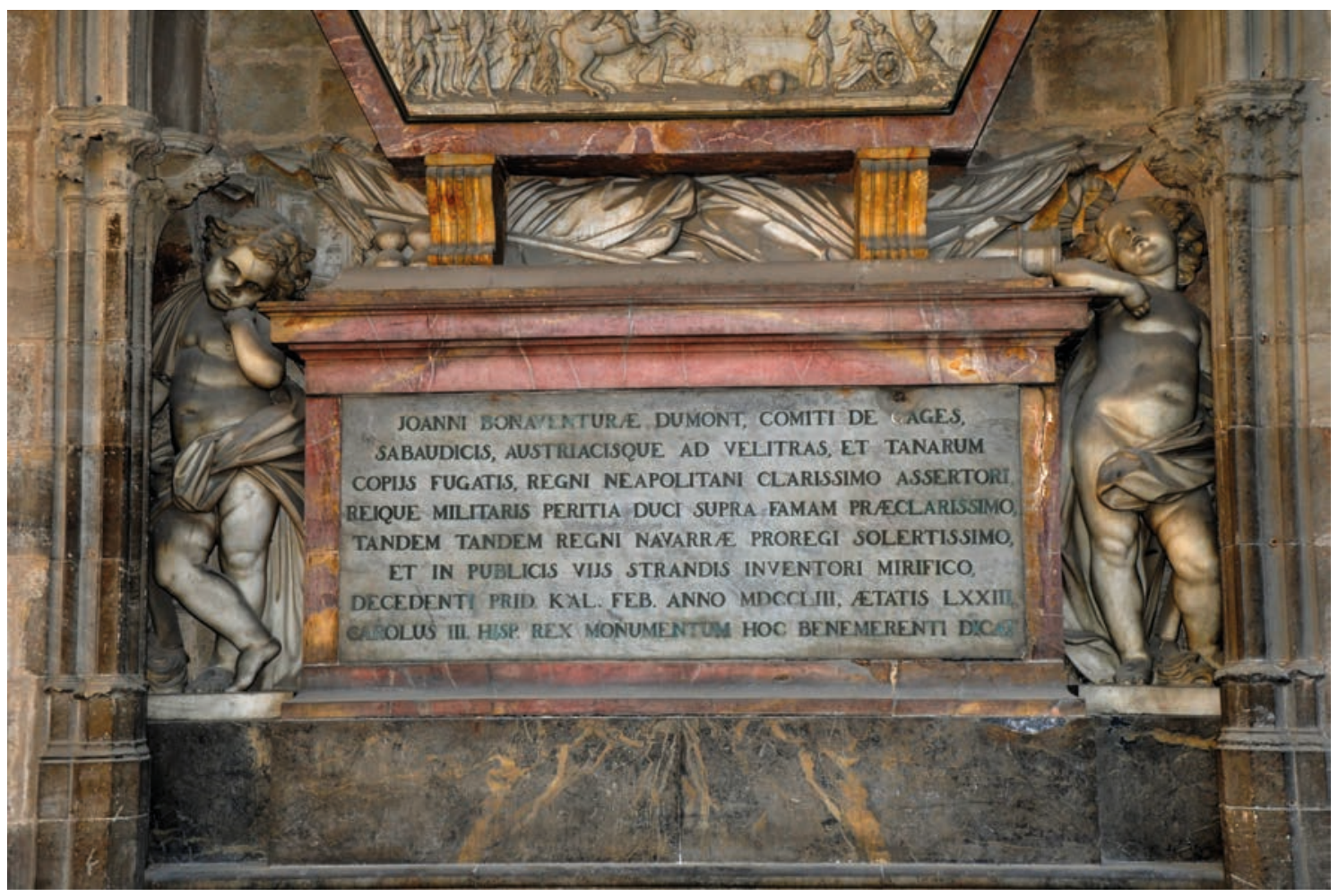

- Fig. 6. Roberto Michel. Sepulcro del conde de Gages. 1767. Detalle del epitafio. Claustro de la Catedral de Pamplona. Foto de la autora.

Sobre esta estructura rectangular descansa la urna trapezoidal con los restos mortales del finado, culminando el conjunto funerario con el busto en mármol blanco del militar y, sobre el mismo y dispuesto en eje el escudo labrado del monarca Carlos III (Fig. 7), y no el emblema heráldico del conde, como en algún caso ha sido descrito. Escudo timbrado con corona real, con campo oval y enmarcado por el collar del Toisón de Oro, del que pende la cruz de la Orden de Carlos III, decorado con elementos vegetales y rocallas, y que se corresponde con el blasón empleado por el monarca a partir de 1760, tal y como ha estudiado Menéndez Pidal ${ }^{50}$. En definitiva, un mausoleo que demuestra el impacto de las grandes sepulturas romanas al adoptar un modelo funerario donde

públicos que se han de trazar. Fallecido el 31 de enero del año 1753, a los setenta y tres años de edad. Carlos III, Rey de las Españas, dedica este monumento al benemérito".

${ }^{50}$ F. MENÉNDEZ PIDAL, El escudo de España, Madrid, 2004, pp. 244-246.

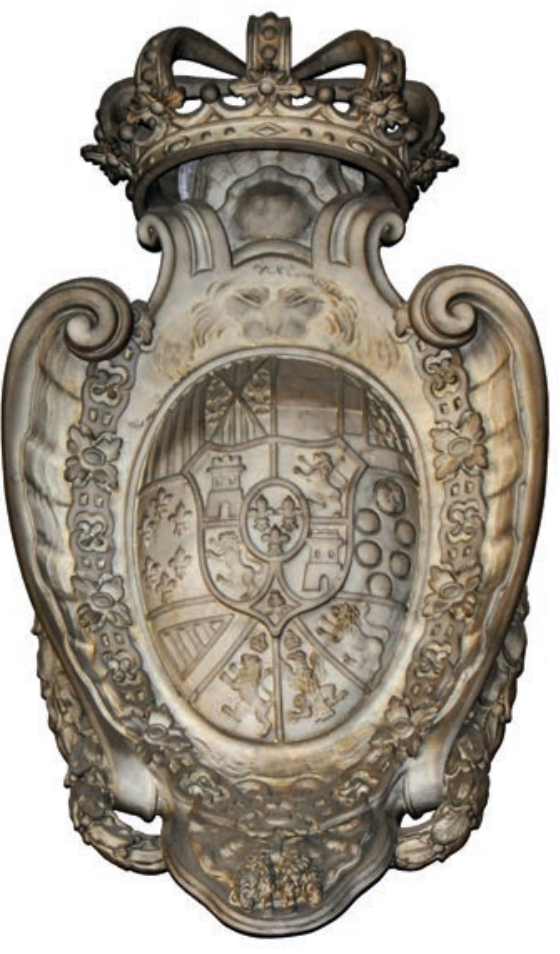

- Fig. 7. Roberto Michel. Sepulcro del conde de Gages. 1767. Detalle del escudo del monarca Carlos III. Claustro de la Catedral de Pamplona. Foto de la autora. 
se dispone un arca con relieves rodeado de figuras alegóricas, en la misma línea de lo que Sabatini diseñó para el sepulcro de Fernando VI, ubicado en la iglesia de las Salesas Reales de Madrid.

No obstante, tal y como se ha mencionado anteriormente, el mausoleo del militar en su primera ubicación originaria de la iglesia de capuchinos también exhibía las armas del conde de Gages, si bien por deseo expreso del patronato privativo del convento franciscano fueron retiradas nada más colocar el sepulcro en el mismo año de 1767, desconociendo por completo qué aconteció con este escudo de armas, así como con las partes de la sepultura realizadas en bronce. Un monumento funerario realizado con jaspe y mármoles de Génova, excelentemente trabajados y pulimentados, con una elevada calidad, tanto en las esculturas del bulto redondo como en aquellas partes labradas en relieve, tratándose en definitiva de una obra de notable interés en el panorama escultórico de la segunda mitad del siglo XVIII español.

Por lo que respecta a las esculturas de bulto redondo de los dos niños dispuestos en pie que centran la inscripción latina, han sido identificadas como Hipnos y Thanatos (Fig. 8) ${ }^{51}$. Ambos -Somnus y Mors en la mitología latina- eran hijos de la Noche y del Érebro y de naturaleza similar ${ }^{52}$, por lo que se les personifica como gemelos, siendo su representación habitual en los sepulcros renacentistas, como ejemplifica el mausoleo de Pedro Enríquez de Ribera en Sevilla ${ }^{53}$, o el del noble aragonés Federico de Urriés,

51 R. FERNÁNDEZ GRACIA, “La escultura funeraria en Navarra durante el Renacimiento y el Barroco", Príncipe de Viana, no 183, 1988, pp. 59-60. ÍDEM, “Los géneros escultóricos"..., pp. 264-265.

${ }^{52} \mathrm{~J}$. L. MORALES Y MARÍN, Diccionario de iconología. Madrid, 1984, pp. 138-139 y 312. C. HARRAUER y H. HUNGER, Diccionario de mitología griega y romana, Barcelona, 2008, pp. 444-446.

53 V. LLEÓ CAÑAL, Nueva Roma: Mitología y humanismo en el Renacimiento Sevillano, Sevilla, 1979, p. 111.
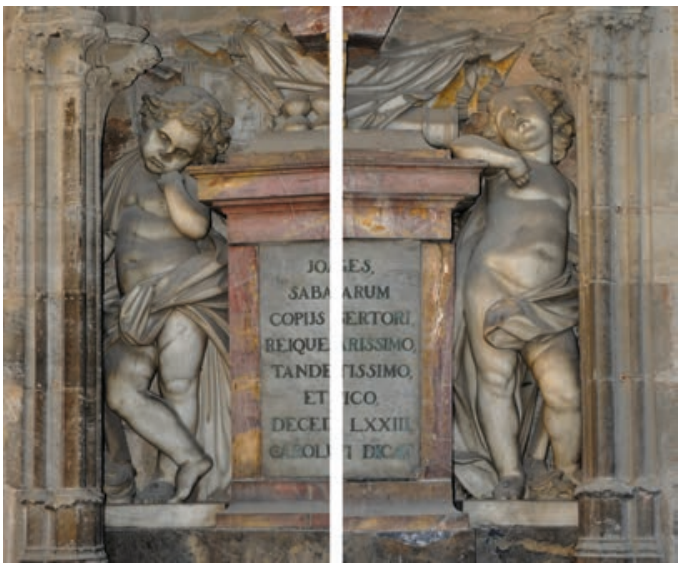

- Fig. 8. Roberto Michel. Sepulcro del conde de Gages. 1767. Detalle de Hipnos y Thanatos. Claustro de la Catedral de Pamplona. Foto de la autora.

atribuido al círculo del italiano Annibale Caccavello en iglesia de Santiago de los Españoles de Nápoles (ca. 1551) ${ }^{54}$. Hipnos, a la izquierda, duerme apoyando la cabeza sobre su mano en complicado contraposto, mientras que Thanatos, a la derecha, llora en actitud declamatoria. Ambos disponen hacia abajo sendas antorchas que sujetan con la otra mano, apenas visibles al quedar encajadas en el interior del rebaje del arcosolio en el que están embutidas, teas que aluden al fin de la vida del conde de Gages, siguiendo una costumbre practicada desde la escultura funeraria romana.

Por su parte, las afamadas hazañas guerreras del difunto están representadas en el mausoleo a través de los trofeos, armas $\mathrm{y}$ pendones que han sido tallados bajo la urna sepulcral y en el relieve esculpido en el frente de ella (Fig. 9). Escena marmórea que narra una memorable acción del ejército español bajo las órdenes directas del conde, la victoria en Bassignano (27 septiembre de 1745) contra los piamonteses y austríacos mandados por el rey de Cerdeña a orillas del río Tánaro en Italia, a la que también alude la inscripción labrada en el sepulcro. En el

${ }^{54}$ J. IBÁÑEZ FERNÁNDEZ, “El diseño para la tumba de Carlos de Aragón y Navarra, obra del escultor napolitano Annibale Caccavello", Goya, nº 341, 2012, pp. 293-295. 


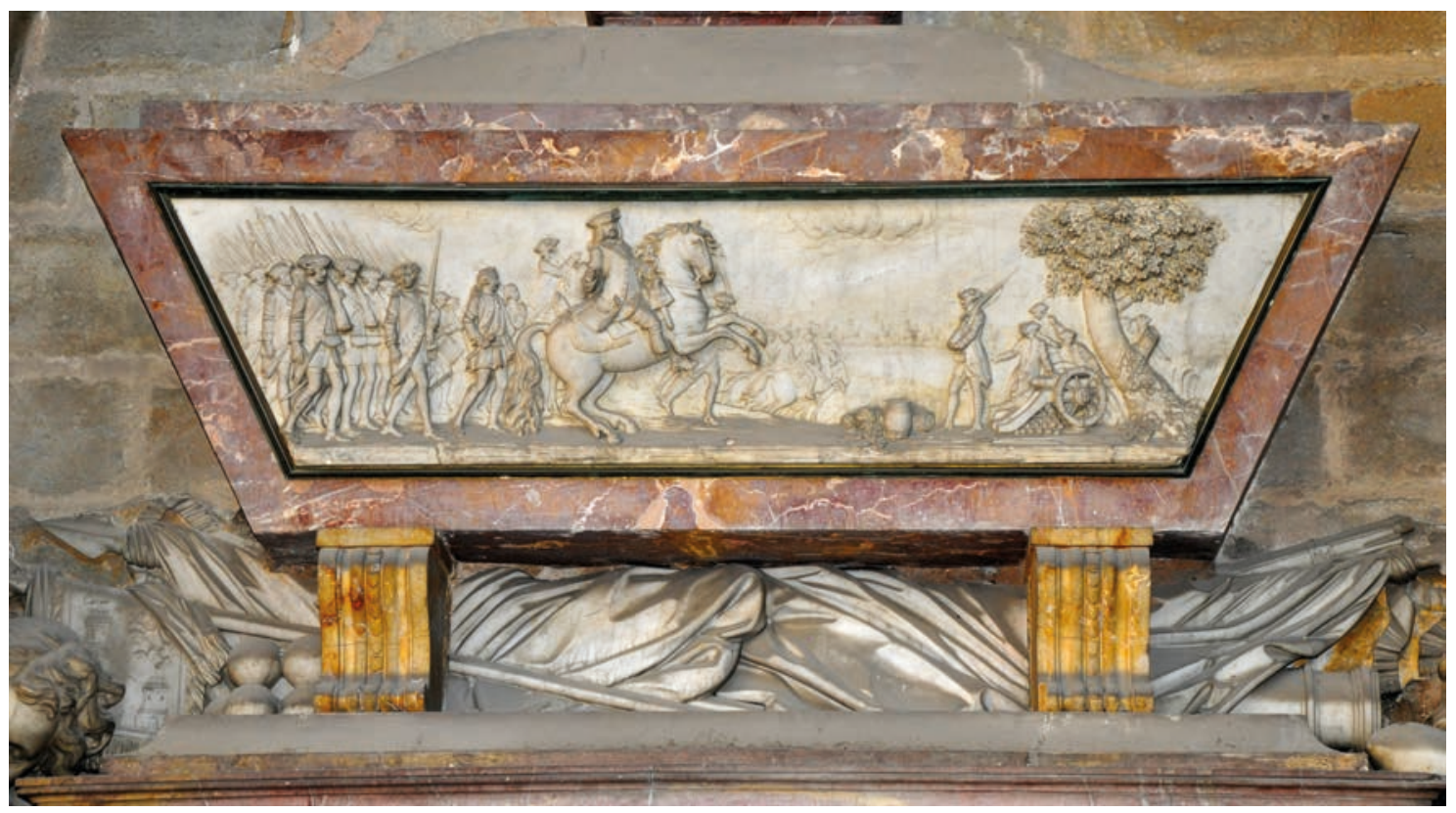

- Fig. 9. Roberto Michel. Sepulcro del conde de Gages. 1767. Detalle del relieve de la urna con la batalla de Bassignano (1745). Claustro de la Catedral de Pamplona. Foto de la autora.

centro del relieve histórico aparece un jinete en corveta tras el que se colocan los alabarderos con casacas y tricornios típicos de la época borbónica, y dispuestos frente a ellos otros soldados con un cañón y útiles de guerra. Relieve que se basa en alguna estampa de la citada batalla, que igualmente se copió en otros grabados del conde, como el que acometió años después para el sobrino del propio virrey el afamado grabador Manuel Salvador Carmona entre 1773 y 1779 (Fig. $10)^{55}$.

Como advirtió Iribarren, la descripción que hizo Víctor Hugo en 1843 del relieve del sepulcro no es literal, al decir que "Hay aquí cañones apuntados, caballos que se encabritan, oficiales que mandan, nutridos batallones que cruzan sus picas y se asemejan a malezas que un viento furioso mezclaría", pues en la obra pétrea tan sólo se esculpió un cañón apoyado en un árbol, y por lo que respecta a las lanzas, no aparecen entrecru-

${ }^{55}$ E. PÁEZ RÍOS, Repertorio de grabados españoles en la Biblioteca Nacional, T. III, Madrid, 1983, p. 103. J. CARRETE PARRONDO, El grabado a buril en la España ilustrada: Manuel Salvador Carmona, Madrid, 1989, p. 103, no 137. R. FERNÁNDEZ GRACIA, “Barroco”, en $L a$ Catedral de Pamplona, vol. II..., pp. 69-71. zadas, sino que los soldados las llevan al hombro, oblicuamente, y casi paralelas unas a otras ${ }^{56}$.

En el extremo inferior izquierdo de este relieve bélico, se labró una inscripción en latín sobre el blanco mármol que refiere la autoría y año de ejecución del mausoleo funerario salido de las manos de Roberto Michel, sobre la que no se había mencionado nada hasta el momento, cuya transcripción literal es: Robertu Michel, Sculpr. Reg; E Directr. sua Acad. I inv. E Scup ${ }^{t}$. Matril. anno $1767^{57}$.

Por último, el busto de Gages (Fig. 11), al igual que otros de los retratos escultóricos salidos de las manos de Michel, como el del monarca Carlos III, es un buen ejemplo de su estilo, refinado y clásico. El conde está efigiado con la dignidad y majestuosidad que requiere la figura del virrey, luciendo el collar del Toisón de Oro que cuelga por una cinta del cuello, y las cruces de las órdenes de San Genaro y Santiago impresas en relieve sobre el manto. Prenda que envuelve los brazos

\footnotetext{
${ }^{56}$ J.M. IRIBARREN, Op.cit., p. 145.

57 Robertu Michel, Sculptor Regis; E Director sua Academia / inventit \& Sculpit. Matril. anno 1767.
} 


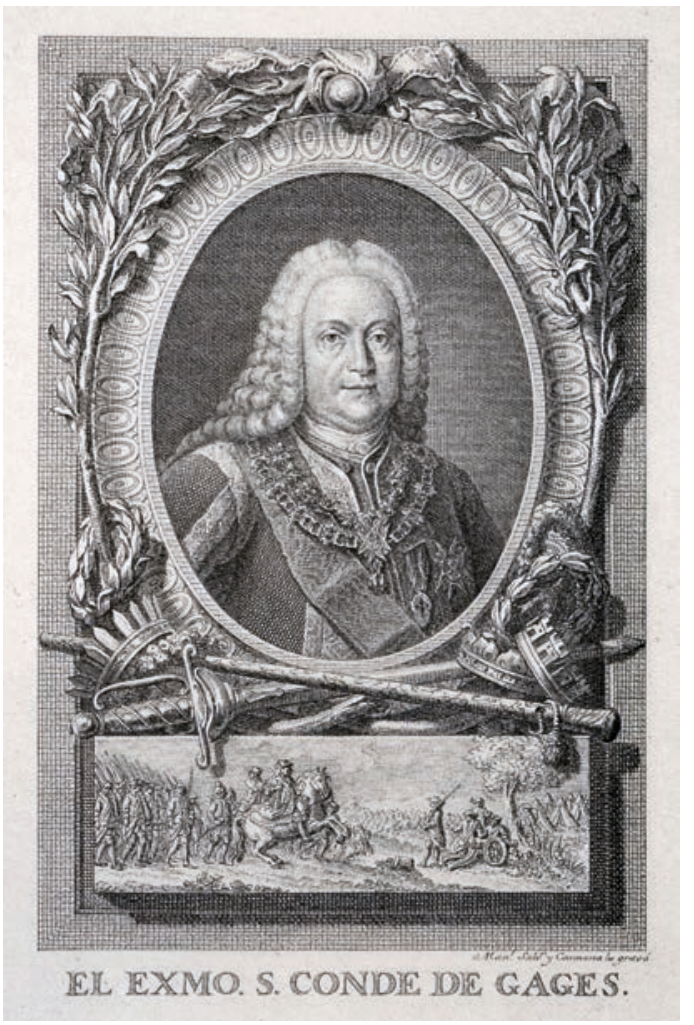

- Fig. 10. Manuel Salvador Carmona. Retrato del conde de Gages. 1773- 1779. Biblioteca Digital Hispánica. Biblioteca Nacional de España.

y el torso y cierra la figura con delicados y elaborados pliegues hasta el nivel inferior de la peana rectangular que sirve de sustento a la imagen. El elaborado ropaje deja al descubierto el hombro derecho, del que cuelga cruzando oblicuamente el torso la banda de capitán general, reproduciendo con gran virtuosismo la finura de la superficie textil de la tela, tallada con finas arrugas. El conde aparece ataviado con una casaca o abrigo largo cerrado con botones planos circulares, y una camisa de cuello alto y corbata de encajes.

El escultor no prescinde del parecido visible, puesto que el rostro enérgico con el que Thiéry mira al infinito, enmarcado por una larga peluca rizada que llega hasta los hombros, acorde a la moda de la época ${ }^{58}$, da

${ }^{58}$ El busto del conde de Gages está tocado por una peluca a la manera de la que presenta la estatua de Fernando VI en pie que Olivieri labró en mármol de Carrara entre 1750-1752 para la fuente del Rey en Aranjuez, actualmente en la Plaza de la Villa de París fe de ese carácter aguerrido y autoritario, que tantos enfrentamientos le ocasionó con las instituciones navarras, tanto con la Diputación, como con el obispo de Pamplona por la cuestión del uso del dosel. Heredero del modelo berninesco, es un retrato que muestra el porte de la elegancia aristocrática, en la mejor línea de la escultura académica dieciochesca, como advirtió Ceán Bermúdez al expresar que "sus obras responden manifestando la anatomía en su lugar, la exactitud de ojo en las proporciones del cuerpo humano, la esbeltez, gracia y ayre de sus figuras, los buenos partidos de paños, la reglas de la composicion y contraste de los grupos y el gusto de los adornos" ${ }^{\prime \prime 5}$.

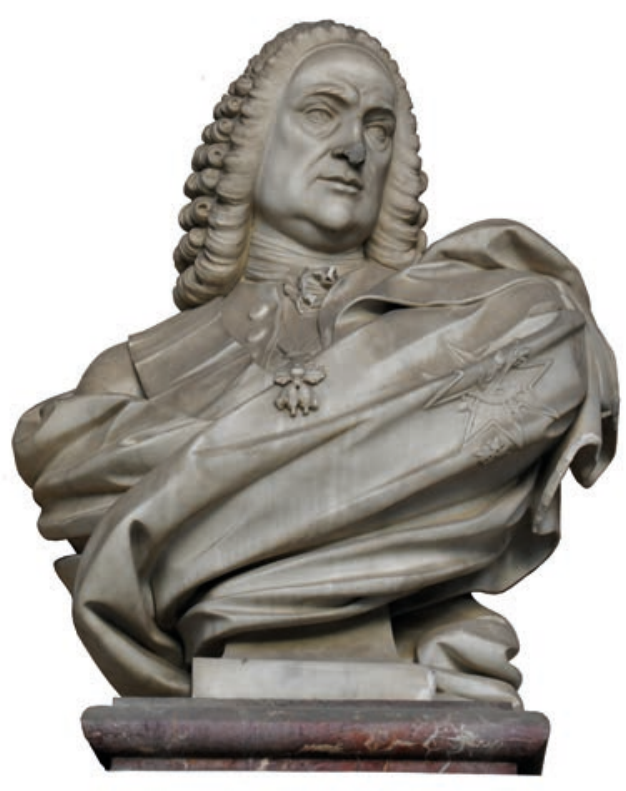

- Fig. 11. Roberto Michel. Sepulcro del conde de Gages. 1767. Detalle del busto del conde de Gages. Claustro de la Catedral de Pamplona. Foto de la autora.

(Madrid). M. L. TÁRRAGA BALDÓ, Giovan Domenico Olivieri y el taller de escultura del Palacio Real, vol. 3, Madrid, 1992, pp. 388-390 y 399. Similar tocado empleó Olivieri en el busto que talló del mismo monarca en 1754 en el mismo material por encargo de la Academia de Bellas Artes de San Fernando para honrar al rey fundador de la misma. Ibídem, pp. 563-565. L. AZCUE BREA, Op.cit., pp. 129-134.

59 J. A. CEÁN BERMÚDEZ, Diccionario histórico de los más ilustres profesores de las Bellas Artes en España, T. III, Madrid, 1800 (ed. Madrid, 1965), pp. 149-150. 
Una escultura que además muestra similitudes en la forma de efigiar al conde de Gages con el busto del rey Fernando VI ejecutado por Olivieri hacia $1752^{60}$. Una obra de mármol de Carrara en la que Michel se pudo inspirar para elaborar el busto retrato del militar, dadas las similitudes que existen entre ambos, desde la majestuosa peluca labrada en dos filas de bucles que prolongan la cabellera que cae sobre los hombros, la manera de representar la insignia del Toisón, que pende de una cinta, o los detalles que presenta la camisa del monarca. Incluso el manto que envuelve la dos figuras, la real y la del conde, en ambos casos se sujeta en el hombro izquierdo, enmarcando elegantemente ambos bustos y dejando a la vista la parte central del torso y el arranque del brazo derecho.

Por su parte Guijarro ha apuntado como modelo de este monumento funerario el sepulcro del rey Fernando VI en la iglesia del convento de las Salesas Reales de Madrid, trazado por Sabatini, en el que también encontramos un cuerpo inferior formado por un largo epitafio, sobre el que descansa la urna trapezoidal, similar a la descrita en el mausoleo del conde de Gages, con un relieve esculpido en su cara frontal. Sin embargo, aunque Roberto Michel sigue en líneas generales este diseño, fruto de la evolución hacia un academicismo depurado, opta en el mausoleo del virrey por reducir significativamente tanto el número de figuras como los elementos escenográficos barroquizantes ${ }^{61}$. Mausoleo que a consecuencia de los diversos traslados que ha sufrido presenta en la actualidad algunos desperfectos, visibles en la rotura de la nariz del busto del conde de Gages o las figuras de Hipnos y Thanatos, a lo que hay que sumar los numerosos grafitis

\footnotetext{
60 M. L. TÁRRAGA BALDÓ, Giovan Domenico Olivieri..., pp. 619-629.

${ }^{61}$ P. GUIJARRO SALVADOR, "Retrato del conde de Gages, virrey de Navarra", en Juan de Goyeneche y el triunfo de los navarros en la Monarquía Hispánica del siglo XVIII, Pamplona, 2005, p. 268.
}

realizados a lápiz y la suciedad acumulada por el paso del tiempo.

Un sepulcro que, a pesar de los distintos cambios de emplazamiento a los que fue sometido, desde la iglesia de capuchinos de Pamplona en 1767, donde quiso reposar el difunto, hasta su traslado al trascoro de la catedral en 1813 para preservarlo de su posible destrucción en tiempos de guerra y su posterior colocación en la crujía occidental del claustro de dicha seo en 1854, donde permanece en la actualidad, sigue teniendo el mismo uso y función con el que fue ejecutado por orden del monarca Carlos III. Un mausoleo que no sólo acoge los restos mortales de Jean Bonaventure Thiéry du Mont, sino que ante todo es un monumento funerario que gracias al excepcional mecenas que lo hizo posible, el monarca Carlos III, y al sobresaliente escultor que le dio vida, Roberto Michel, ejecutando una obra artística de exquisita calidad, merecedora de la atención de cuántos visitantes, eruditos o no, tuvieron la fortuna de contemplarlo, ha conseguido mantener viva la fama postuma del conde de Gages y sus destacadas gestas militares hasta nuestros días.

\section{BIBLIOGRAFÍA}

ALVARADO, F. de, Guía del viajero en Pamplona, Madrid, 1904.

AZCONA, T. de, El convento de Capuchinos Extramuros de Pamplona (1606-2006), Pamplona, 2006.

“El P. Tomás de Burgui y su libro sobre San Miguel de Excelsis", Boletín de la Real Sociedad Vascongada de los Amigos del País, LXIV, 2008, pp. 933-961.

AZCUE BREA, L., La escultura en la Real Academia de Bellas Artes de San Fernando. Catálogo y estudio, Madrid, 1994.

BURGO, J. del, Historia General de Navarra. Desde los orígenes hasta nuestros días, t. III, Madrid, 1992.

BURGUI, T. de, Retrato vivo del héroe bélgicohispano ya difunto: Epicedio obsequioso, que 
la Seraphica Comunidad de RR. PP. Capuchinos de Pamplona consagró el día 3 de Febrero en sus primeras exequias a la celebre memoria de su insigne bienhechor, el Excelentissimo Don Juan Buenaventura Dumont, Conde de Gages, Capitan General, y Virrey del Reyno de Navarra, Pamplona, 1753.

Honras del excelentísimo conde de Gages, Virrey de Navarra y del catholico rey de España don Fernando VI, predicadas en Pamplona por el Padre Fray Thomas de Burgui, Madrid, 1766.

CABODEVILLA, F. J., Escritores de las antiguas Provincias Capuchinas de Aragón y Navarra (1608-1900), Pamplona, 2004.

CÁMARA MUÑOZ, A., Los ingenieros militares de la monarquía hispánica en los siglos XVII y XVIII, Madrid, 2005.

CARRETE PARRONDO, J., El grabado a buril en la España ilustrada: Manuel Salvador Carmona, Madrid, 1989.

CEÁN BERMÚDEZ, J. A., Diccionario histórico de los más ilustres profesores de las Bellas Artes en España, T. III, Madrid, 1800 (ed. Madrid, 1965).

CROCE, B., En la Península Ibérica. Cuaderno de Viaje (1889), (trad. y notas de Félix Fernández Murga), Sevilla, 1993.

DÍAZ CACHERO, T., “Thierry Dumont, Juan Buenaventura", en Gran Enciclopedia de Navarra, vol. X, Pamplona, 1990, p. 472.

FELICES DE LA FUENTE, M. M., La nueva nobleza titulada de España y América en el siglo XVIII (1701-1746). Entre el mérito y la venalidad, Almería, 2012.

- Condes, marqueses y duques: biografías de nobles titulados durante el reinado de Felipe $V$, Madrid, 2013.

FERNÁNDEZ GRACIA, R., “La escultura funeraria en Navarra durante el Renacimiento y el Barroco", Príncipe de Viana, no 183, 1988, pp. 51-69.

"Barroco", en La Catedral de Pamplona, vol. II, Pamplona, 1994, pp. 34-73.
FERNÁNDEZ GRACIA, R. (coord.), ANDUEZA UNANUA, P., AZANZA LÓPEZ, J. J. y GARCÍA GAINZA, M. C., El arte del Barroco en Navarra, Pamplona, 2014.

FERNÁNDEZ GRACIA, R., "Los géneros escultóricos", en R. FERNÁNDEZ GRACIA (coord.), P. ANDUEZA UNANUA, J. J. AZANZA LÓPEZ y GARCÍA GAINZA, El arte del Barroco en Navarra, Pamplona, 2014, pp. 175-271.

GARCÍA GAINZA, M. C., Escultura cortesana del siglo XVIII, Madrid, "Historia 16", $\mathrm{n}^{-}$92, 1993.

GARCÍA GAINZA, M. C., HEREDIA MORENO, M. C., RIVAS CARMONA, J. y ORBE SIVATTE, M. Catálogo Monumental de Navarra, II**. Merindad de Estella, Pamplona, 1983.

GARCÍA GAINZA, M. C., ORBE SIVATTE, M., DOMEÑO MARTÍNEZ DE MORENTIN, A. y AZANZA LÓPEZ, J. J., Catálogo Monumental de Navarra, $V^{* * *}$. Merindad de Pamplona, Pamplona, 1997.

GOÑI GAZTAMBIDE, J., “La capilla del trascoro de la catedral de Pamplona", en Hispania christiana: estudios en honor del prof. Dr. José Orlandis Rovira en su septuagésimo aniversario, Pamplona, 1988, pp. 685-718.

GUIJARRO SALVADOR, P., "Retrato del conde de Gages, virrey de Navarra", en Juan de Goyeneche y el triunfo de los navarros en la Monarquía Hispánica del siglo XVIII, Pamplona, 2005, pp. 268-269.

GUTIÉRREZ MARCOS, M. R., “Roberto Michel: introductor del clasicismo francés en la imaginería de la iglesia de San José de Madrid", Ars et sapientia, no 23, 2007, pp. 45-62.

HARRAUER, C. y HUNGER, H., Diccionario de mitología griega y romana, Barcelona, 2008.

HUGO, V., Los Pirineos (trad. Victoria Argimón), Palma de Mallorca, 2000. 
IBÁÑEZ FERNÁNDEZ, J., “El diseño para la tumba de Carlos de Aragón y Navarra, obra del escultor napolitano Annibale Caccavello", Goya, no 341, 2012, pp. 290299.

IDOATE, F., "Virreinato del conde de Gages", en Rincones de la historia de Navarra, vol. III, Pamplona, 1979, pp. 104-108.

IRIBARREN, J. M., Pamplona y los viajeros de otros siglos, Pamplona, 1986.

LARUMBE MARTÍN, M., El academicismo y la arquitectura del siglo XIX en Navarra, Pamplona, 1990.

"Neoclasicismo", en La Catedral de Pamplona, vol. II, Pamplona, 1994, pp. 74-89.

LLEÓ CAÑAL, V., Nueva Roma: Mitología y humanismo en el Renacimiento Sevillano, Sevilla, 1979.

LÓPEZ GÓMEZ, A. y MANSO PORTO, C., Cartografía del siglo XVIII: Tomás López en la Real Academia de la Historia, Madrid, 2006.

LORENTE ARÉVALO, C. y TASCÓN GÁRATE, C., "Nuevas aportaciones a la biografía del escultor Roberto Michel", Anales de Historia del Arte, no 5, 1995, pp. 225-236.

MADOZ, P., Diccionario geográfico-estadísticohistórico de Navarra, Valladolid, 1986.

MARTÍN GONZÁLEZ, J. J., Escultura barroca en España, 1600-1770, Madrid, 1983.

MELENDRERAS GIMENO, J. L., "La obra de Roberto Michel escultor de Cámara del Rey Carlos III", Reales sitios, no 90, 1986, pp. 37-44.

MENDIOROZ LACAMBRA, A., "El conde de Gages, virrey de Navarra durante 1749-1753", Cuadernos del Marqués de San Adrián, nํ5, 2007, pp. 119-152.

MENÉNDEZ PIDAL, F., El escudo de España, Madrid, 2004.

MOLINS MUGUETA, J. L., Capilla de San Fermín en la iglesia de San Lorenzo de Pamplona, Pamplona, 1974.
"Las capillas de San Fermín y de Nuestra Señora del Camino en Pamplona", en M. C. GARCÍA GAINZA (coord.), El arte en Navarra. 2. Renacimiento, Barroco y del Neoclasicismo al arte actual, Pamplona, 1994, pp. 417-432.

"Trazas y dibujos de la antigua Casa Consistorial de Pamplona", en R. FERNÁNDEZ GRACIA (coord.), Pulchrum. Scripta Varia in honorem $M^{a}$ Concepción García Gainza, Pamplona, 2011, pp. 555567.

MOLINS MUGUETA, J. L. y FERNÁNDEZ GRACIA, R., "La capilla de Nuestra Señora del Camino", en La Virgen del Camino de Pamplona. IV Centenario de su aparición (1487-1997), Pamplona, 1987, pp. 61-117.

MORALES Y MARÍN, J. L., Diccionario de iconología. Madrid, 1984.

PÁEZ RÍOS, E., Repertorio de grabados españoles en la Biblioteca Nacional, T. III, Madrid, 1983.

PONZ, A., Viage fuera de España, (ed. Mónica Bolufer Peruga), Alicante, 2007.

RIVAS CARMONA, J., "El trascoro de Pamplona: el valor de la tradición catedralicia", en M. C. GARCÍA GAINZA y R. FERNÁNDEZ GRACIA (coords.), Cuadernos de la Cátedra de Patrimonio y Arte Navarro, $n^{0}$ 1. Estudios sobre la catedral de Pamplona in memoriam Jesús María Omeñaca, Pamplona, 2006, pp. 259-272.

ROMERA, J. M., Pamplona-Iruña. Imágenes y palabras, Pamplona, 1997.

SÁNCHEZ CANTÓN, F. J., "Roberto Michel, escultor del siglo XVIII", Boletín de la Sociedad Española de Excursiones, XXV, 1917, pp. 4-6.

SÁNCHEZ RIVERA, J. A., "Robert Michel en la iglesia de las Comendadoras de Santiago", Anales del Instituto de Estudios Madrileños, L, 2010, pp. 353-373.

TÁRRAGA BALDÓ, M. L., “Los estucos de Roberto Michel para el palacio de El Par- 
do", Archivo Español de Arte, LXII, no 247, 1989, pp. 315-329.

"Carlos III y la escultura cortesana", Reales Sitios, no 99, 1989, pp. 35-44.
_ Giovan Domenico Olivieri y el taller de escultura del Palacio Real, Madrid, 1992. 